\title{
Membangun siswa literat melalui edukasi dan proyek literasi
}

\section{Sri Hapsari Wijayanti ${ }^{\star}$}

\author{
Fakultas Ekonomi dan Bisnis, Universitas Katolik Indonesia Atma Jaya, Indonesia \\ *sri.hapsari@atmajaya.ac.id
}

\begin{abstract}
Reading literacy competence is an educational problem that requires special attention and needs continuously improved. Reading literacy should begin earliest in the family environment. After entering the school, teachers need to work together with parents to raise a reading culture. Public of Elementary School (SDN) Pulau Kelapa 01 Pagi has not involved parents yet before in encouraging students to read. Therefore, the purposes of this activity are to educate parents about the importance of reading literacy and evaluating the Literacy Project assigned to parents. This community service activity uses the method to educate parents with tutorials, discussion, and experience sharing techniques. After opening the mindset and giving the knowledge about literacy reading, participants, namely the parents of 29 fourth grade students, were given a Literacy Project assignment for a week. This activity has increased the attention of parents about the importance of reading and fostering reading through the family environment. However, in fact, in the implementation of the Literacy Project, parents have not yet fully carried out. Parents still need to implement reading habits at home. In this case, the school needs to collaborate with parents in creating a pleasant literacy atmosphere through various literacy activities in a sustainable manner. Universities can help realize these programs.
\end{abstract}

\begin{abstract}
Absrak Kemampuan literasi membaca merupakan urgensi pendidikan yang perlu mendapat perhatian khusus dan terus-menerus dibina. Literasi membaca seyogianya dimulai sejak dini dari lingkungan keluarga. Setelah masuk ke jenjang pendidikan, sekolah perlu bersinergi dengan orang tua untuk membantu membangkitkan budaya membaca di kalangan siswa. SDN Pulau Kelapa 01 Pagi di Kepulauan Seribu belum melibatkan orang tua dalam mendorong siswa untuk gemar membaca. Oleh karena itu, tujuan kegiatan ini adalah mengedukasi orang tua siswa akan pentingnya literasi membaca dan menjalankan serta mengevaluasi Proyek Literasi yang ditugaskan kepada orang tua. Untuk mencapai tujuan itu, metode yang digunakan adalah edukasi, diskusi, dan sharing pengalaman. Sesudah mengedukasi literasi membaca, peserta, yaitu orang tua siswa kelas IV yang berjumlah 29 orang, diberikan tugas Proyek Literasi selama seminggu. Kegiatan ini telah menumbuhkan rasa peduli orang tua akan pentingnya membaca dan membudayakan membaca melalui lingkungan keluarga meskipun dalam waktu penugasan yang sangat singkat. Namun, dalam pelaksanaan proyek, hanya separuh orang tua yang menjalankannya. Orang tua masih membutuhkan pendampingan dalam menerapkan kebiasaan membaca di rumah. Dalam hal ini pihak sekolah perlu bekerja sama dengan orang tua untuk menciptakan suasana literasi yang menyenangkan melalui berbagai kegiatan literasi secara berkesinambungan. Adapun pihak perguruan tinggi dapat membantu merealisasikan program.
\end{abstract}

Keywords: education; literacy; family literacy movement; character; Kepulauan Seribu; reading interest; merdeka belajar; elementary school

\section{OOPEN ACCESS}

Citation: Wijayanti., S. H. (2020). Membangun siswa literat melalui edukasi dan proyek literasi. Riau Journal of Empowerment, 3(3), 127-137. https://doi.org/10.31258/raje.3.3.127-137

Paper type: Community service

Received: 2020-02-29 Revised: 2020-07-15 Accepted: 2020-08-14

Language: Bahasa Indonesia (id)

Funding: Fakultas Ekonomi dan Bisnis, Universitas Katolik Indonesia Atma Jaya, Indonesia

ISSN 2623-1549 (online), 2654-4520 (print)

(C) 2020 Sri Hapsari Wijayanti. Author(s) retain the copyright of article published in this journal, with first publication rights granted to Riau Journal of Empowerment. The article is licenced under Creative Commons Attribution 4.0 International License. This license permits unrestricted use, distribution, and reproduction in any medium, provided the original author and source are credited. 


\section{PENDAHULUAN}

Untuk menghasilkan sumber daya manusia yang dapat bertahan dalam perubahan zaman dan tantangan kehidupan yang terus berubah, diperlukan kecakapan hidup abad ke-21 sehingga sumber daya manusia Indonesia dapat bersaing secara nasional dan internasional. Sumber daya manusia sejak sekolah dasar perlu dipersiapkan. Sekolah dasar merupakan jenjang pendidikan awal dalam membentuk kecakapan hidup abad ke-21. Kecakapan abad ke-21 meliputi literasi dasar, kompetensi, dan kualitas karakter. Salah satu kecakapan hidup yang penting dibina sejak dini adalah literasi membaca. Literasi membaca terkait dengan minat baca. Keduanya merupakan persoalan serius bangsa Indonesia (Atmazaki et al., 2017).

Masalah minat membaca yang belum membudaya di Indonesia mendorong pemerintah pada 2016 menggagas Gerakan Literasi Nasional (GLN) dan Merdeka Belajar melalui implementasi literasi membaca pada 2020 sebagai fokus pengembangan sumber daya manusia (Wardi, 2020). Hal ini menunjukkan bahwa masalah literasi dasar membaca memerlukan perhatian serius karena bukan saja berdampak pada intelektual individu, melainkan juga kemampuan daya saing di kancah internasional. Gerakan literasi membaca melalui GLN bertujuan "menumbuhkembangkan budaya literasi pada ekosistem pendidikan mulai dari keluarga, sekolah, dan masyarakat dalam rangka pembelajaran sepanjang hayat sebagai upaya untuk meningkatkan kualitas hidup" (Atmazaki et al., 2017). Untuk menciptakan budaya membaca, dibutuhkan kolaborasi para pemangku kepentingan, yaitu pemerintah, masyarakat, sekolah, orang tua, dan penerbit. Karena itu, GLN diterapkan dalam tiga ranah, yaitu ranah sekolah (GLS), masyarakat (GLM), dan keluarga (GLK).

Gerakan keluargaLiterasi keluarga Keluarga (GLK) menekankan penciptaan budaya membaca dalam lingkup keluarga. Sebagai unit terkecil masyarakat, di lingkungan keluarga, karakter positif dapat dibentuk sejak dini. Keluarga merupakan lingkungan pembelajaran pertama dan utama bagi anak-anak (Atmazaki et al., 2017) dan orang tua adalah pendidik yang pertama bagi anak. Pembiasaan membaca dari keluarga akan berpengaruh besar pada pendidikan di sekolah (Sandjaja, 2001). Hal itu didukung Susan dan Berthelsen (2014) bahwa rumah adalah konteks penting dalam mengembangkan literasi membaca sejak dini dan orang tua dapat mendorong dan mendukung anak membaca sehingga tumbuh kegemaran anak akan bacaan (Hidayat, 2017). Gemar membaca merupakan sarana untuk membentuk karakter mulia yang menjadi tujuan akhir pendidikan (Antoro, 2018).

Kebiasaan membaca akan tercipta jika lingkungan sekolah mendukung, seperti ketersediaan bacaan di perpustakaan sekolah (Wijayanti et al., 2012). Akan tetapi, peran lingkungan rumah juga tidak kalah penting. Jika di rumah tidak ada anggota keluarga yang senang membaca, siswa tidak mendapat model orang terdekat yang suka membaca. Akan tetapi, jika di sekolah guru mentubi dengan kebiasaan membaca, siswa lama-kelamaan akan tumbuh rasa suka membaca. Baik keluarga maupun guru dapat bersinergi menumbuhkan minat membaca dengan menciptakan perasaan senang ketika siswa membaca bacaan yang sesuai dengan usia mereka. Di tingkat sekolah, jika guru dapat menanamkan dan menciptakan pada siswa nilai-nilai positif membaca, kemungkinan siswa akan terus membaca dengan percaya diri pada masa-masa selanjutnya (Palani, 2012).

Salah satu Sekolah Dasar di Kepulauan Seribu yang sudah membudayakan membaca sejak 2016 adalah Sekolah Dasar Negeri (SDN) Pulau Kelapa 01 Pagi. Akan tetapi, sekolah tersebut belum menjalankan kebiasaan membaca minimal lima belas menit buku nonpelajaran sebelum belajar sebagai salah satu bentuk aktivitas GLS (Kementerian Pendidikan dan Kebudayaan, 
2016). Meskipun kegiatan GLS yang sebenarnya belum berjalan, lingkungan sekolah sudah memperlihatkan suasana literasi yang mendukung budaya baca-tulis. Terbukti sudah ada ekstrakurikuler majalah dinding (mading) yang dapat dilihat di dalam dan di luar kelas serta adanya pojok baca di hampir semua kelas. Selain itu, perpustakaan sekolah sudah mengoleksi buku yang bervariasi. Siswa secara bergilir mendatangi perpustakaan sesuai dengan jadwal. Begitu juga guru secara bergiliran menjaga perpustakaan.

Sayangnya, pihak sekolah belum melibatkan orang tua dalam menumbuhkan atau meningkatkan minat baca. Di SDN Pulau Kelapa 01 Pagi, yang dipilih sebagai mitra kegiatan pengabdian kepada masyarakat karena merupakan sekolah teladan di Kepulauan Seribu, masih ditemukan siswa kelas IV yang belum lancar membaca. Orang tua, menurut penjelasan guru, masih sepenuhnya menyerahkan pendidikan kepada pihak sekolah. Akibatnya, guru melakukan pekerjaan ekstra untuk mengajarkan siswa membaca di luar jam sekolah atau memberikan tugas-tugas terkait literasi baca-tulis di luar sekolah. Maka, kegiatan pengabdian kepada masyarakat yang akan dilakukan adalah mengedukasi orang tua siswa akan pentingnya literasi membaca dan menerapkan Proyek Literasi kepada orang tua dalam upaya pembiasaan membaca.

\section{METODE PENERAPAN}

Peserta kegiatan di SDN Pulau Kelapa 01 Pagi di Kepulauan Seribu ini adalah orang tua siswa kelas IV berjumlah 29 orang. Kegiatan dilakukan selama tiga hari pada_16 hingga 18 Oktober 2019. Tahapan kegiatan adalah sebagai berikut.

Pertama, kegiatan ini diawali dengan persiapan. Dalam tahap ini, Pengabdi mengumpulkan data mengenai profil orang tua.

Kedua, pelaksanaan kegiatan. Kegiatan berbentuk edukasi kepada orang tua. Edukasi disampaikan secara tutorial, diskusi, dan berbagi pengalaman (sharing). Kegiatan ini diakhiri dengan pemberian Proyek literasi dari orang tua (diwakili oleh ibu) untuk anaknya di rumah. Proyek Literasi adalah kegiatan bersama antara orang tua dan anak dalam bentuk membaca buku cerita dalam waktu satu minggu. Siswa dapat sekadar membaca buku atau dan meringkas isi buku yang dibacanya. Semua dalam pengawasan orang tua. Di sini dibutuhkan peran aktif ibu dalam mengawal kegiatan literasi anaknya hingga tuntas membaca buku cerita. Judul apa yang dibaca dan kapan waktu membaca dicatat di lembar observasi. Proyek ini selain bekerja sama dengan orang tua juga dengan guru kelas. Orang tua melaksanakan kegiatan literasi bersama anak, yaitu membaca bersama, membimbing, mengawasi, atau mengingatkan anak untuk membaca. Guru kelas mendorong siswa untuk membaca minimal buku yang dipinjami sekolah, baik dibaca di rumah maupun di kelas.

Ketiga, pelaksanaan dan evaluasi kegiatan Proyek Literasi. Evaluasi dilakukan dengan mengumpulkan hasil observasi dari orang tua kepada Pengabdi, kemudian diungkap tingkat keberhasilan proyek dan kendala yang dihadapi. 


\section{HASIL DAN KETERCAPAIAN SASARAN}

\section{Demografi Peserta}

Peserta kegiatan ini terdiri atas orang tua siswa, yang diwakili oleh ibu atau nenek siswa. Jumlah peserta kegiatan ini 29 orang. Usia mereka 21-66 tahun dengan pendidikan mayoritas lulusan SD (29\%) (Gambar 1) dan mayoritas memiliki jumlah anak sebanyak 2 orang (42\%) (Gambar 2).

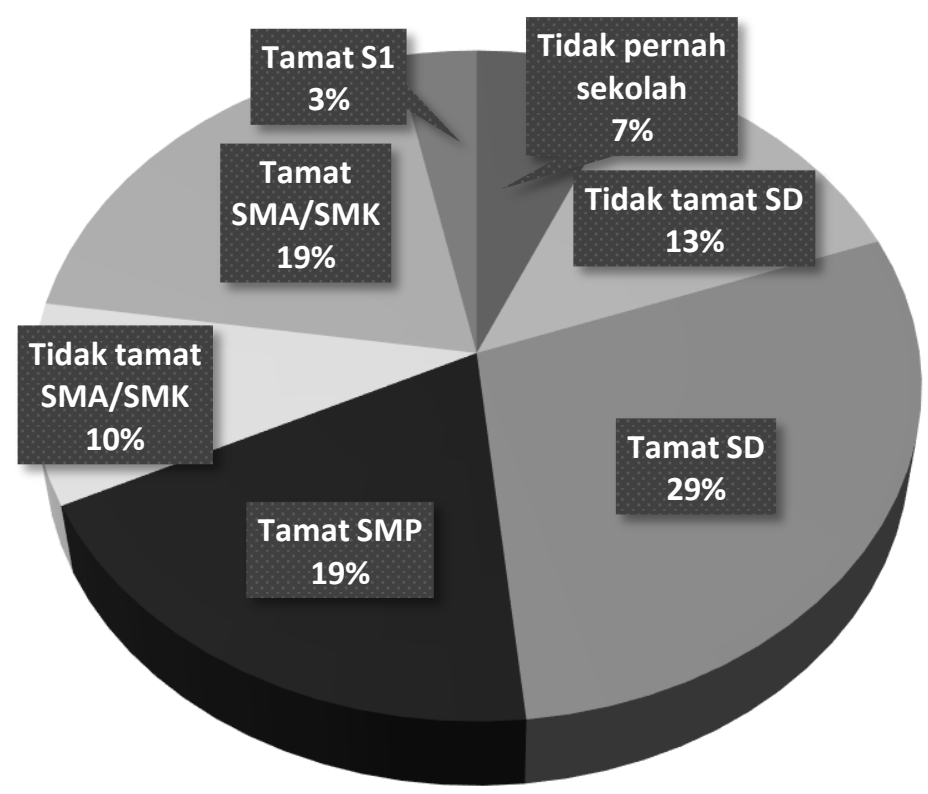

Gambar 1. Latar belakang pendidikan orang tua

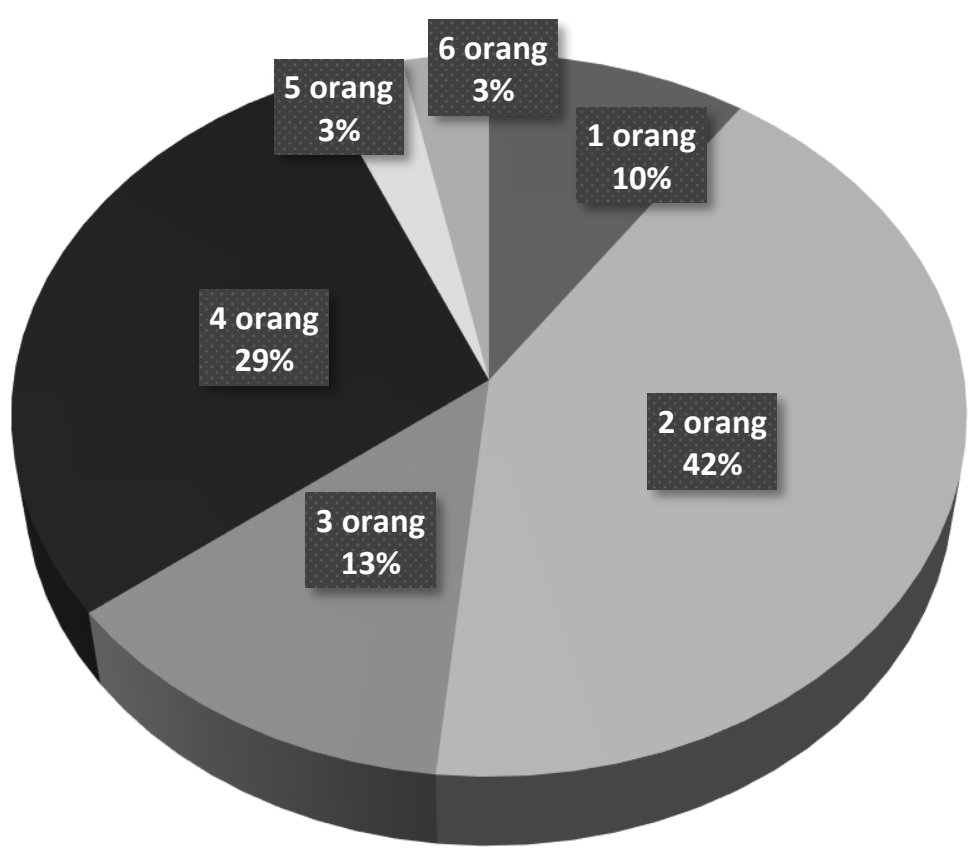

Gambar 2. Jumlah anak dalam keluarga

Pekerjaan kepala keluarga umumnya nelayan $(79,83 \%)$, sisanya karyawan swasta $(7,45 \%)$, wiraswasta (5,35\%), buruh (3,72\%), dan PNS (3,6 \%) (Profil Sekolah SDN Pulau Kelapa 01 
Pagi, 2018). Pendapatan tetap kepala keluarga kurang dari Rp 1 juta (49\%) (Gambar 3). Sejumlah $29 \%$ peserta mempunyai usaha sampingan sebagai pedagang keliling (40\%), tukang becak, tukang galon, tukang becak, masing-masing 20\% (Gambar 4). Data tersebut menjelaskan bahwa latar belakang pendidikan dan ekonomi orang tua siswa di SD Pulau Kelapa 01 Pagi tergolong rendah. Mayoritas (71\%) mengandalkan gaji bulanan, sedangkan $29 \%$ dari mereka-meskipun umumnya tidak memiliki jumlah anak yang banyak-mencari tambahan penghasilan untuk mencukupi kebutuhan keluarga. Ada yang berdagang keliling atau membuka usaha rumahan.

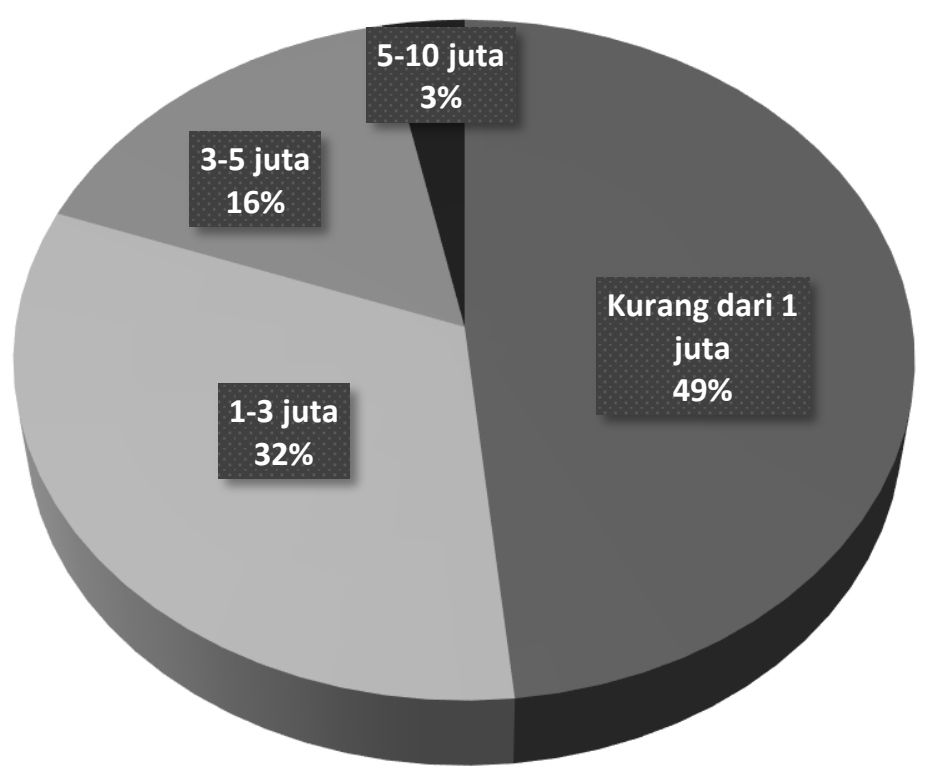

Gambar 3. Rata-rata pendapatan kepala keluarga per bulan

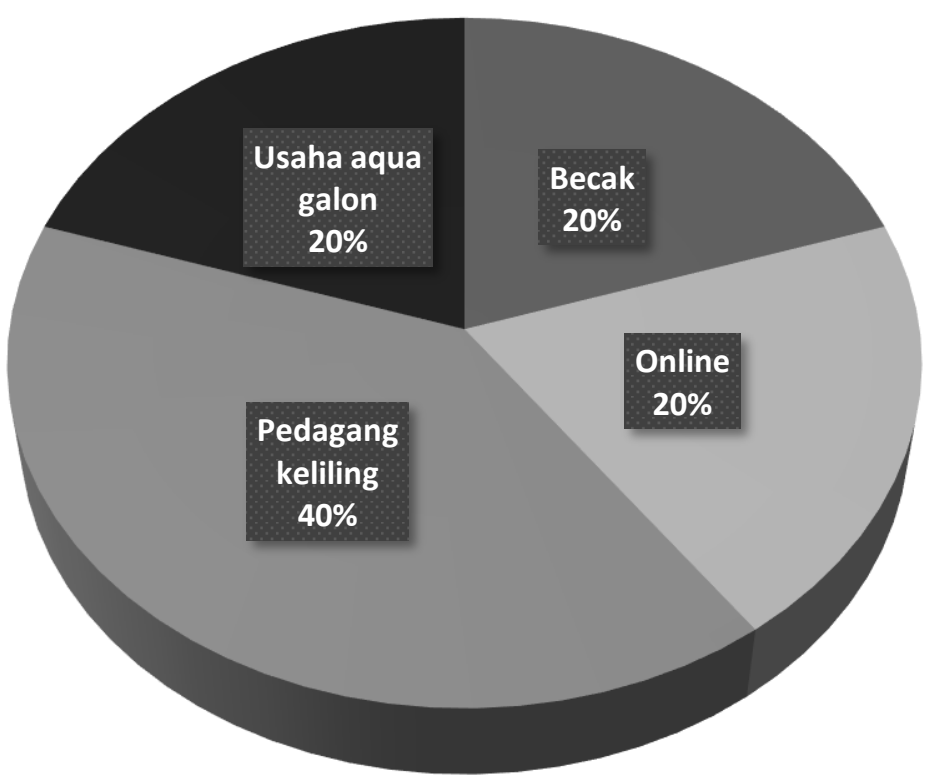

Gambar 4. Jenis usaha sampingan peserta 


\section{Edukasi Literasi kepada Orang Tua Siswa}

Pengabdi melakukan sosialisasi kegiatan di hadapan Wakil Kepala Sekolah dan para guru yang berjumlah enam belas orang (Gambar 5). Dalam sosialiasi diuraikan tujuan kegiatan pengabdian kepada masyarakat, yaitu memberikan edukasi literasi membaca kepada orang tua siswa kelas IV. Pemilihan kelas didasarkan pertimbangan yang diputuskan bersama guru bahwa siswa kelas IV diasumsikan sudah lancar membaca. Total siswa kelas IV berjumlah 39 siswa dari dua rombongan belajar. Dalam sosialisasi itu, Pengabdi mendapat dukungan penuh dari pihak sekolah. Kegiatan literasi, menurut guru, merupakan bagian dari rencana sekolah yang belum terealisasi dan secara kebetulan salah satu guru baru saja mengikuti training literasi dan akan menerapkannya di sekolah.

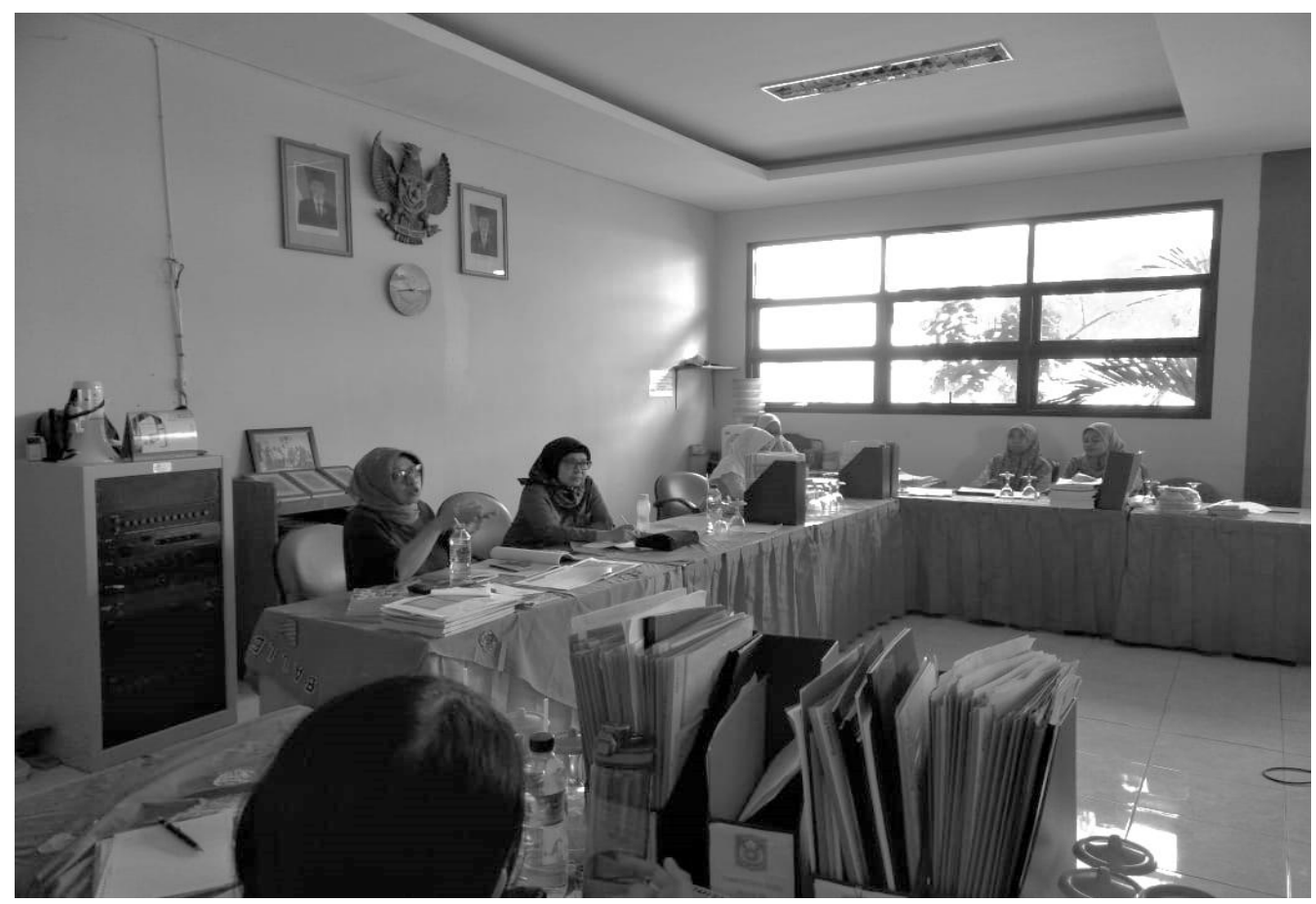

Gambar 5. Sosialisasi kegiatan

Sebelum edukasi dilaksanakan, peserta orang tua atau wali siswa diminta mengisi kuesioner yang berisi latar belakang keluarga. Dari pengisian kuesioner, diketahui tidak semua yang hadir adalah orang tua (ibu), tetapi ada juga nenek dari siswa. Beberapa peserta kurang memahami isi kuesioner, bahkan ada yang tidak dapat membaca sehingga dilakukanlah pengarahan dan pendampingan pengisian kuesioner. Setelah kuesioner selesai diisi, Pengabdi menyampaikan materi terkait literasi di dalam keluarga dalam suasana informal kepada 29 peserta yang hadir di ruang perpustakaan sekolah (Gambar 6). Dalam edukasi ini, para ibu juga berkesempatan untuk saling berbagi cerita dan bertukar pikiran.

Meskipun peserta mengetahui pentingnya membaca sejak dini, umumnya mereka mengalami kesulitan ketika mengajak anaknya untuk membaca karena tidak ada buku lain di rumah selain buku pelajaran sekolah. Di samping itu, ibu sudah disibukkan dengan pekerjaan rumah tangga atau jika harus bekerja di luar rumah, mereka menyerahkan anaknya untuk diasuh neneknya. Dari informasi guru dan sharing kegiatan ini, terungkap masih banyak ibu yang menganggap sekolahlah yang bertanggung jawab penuh terhadap pendidikan anak mereka. 


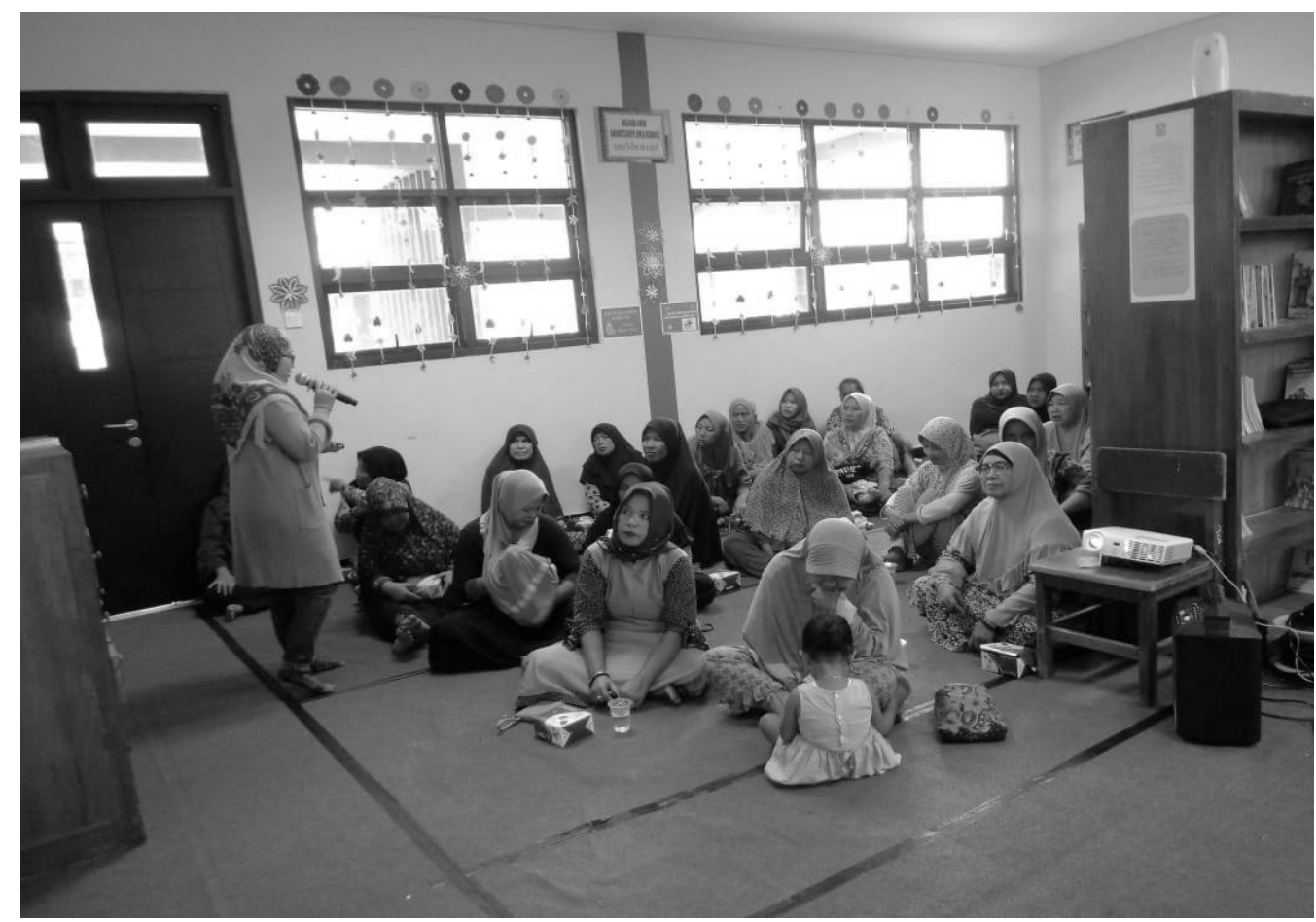

Wijayanti

Gambar 6. Edukasi literasi membaca

Edukasi literasi telah membuka pandangan dan wawasan orang tua siswa kelas IV mengenai pentingnya pembiasaan membaca dibina sejak dini. Hal ini terbukti dari orang tua siswa yang mengakui baru memahami apa dan bagaimana penerapan literasi, antusias bertanya, dan berbagi pengalaman. Kendati sebaiknya anak dilatih gemar membaca sejak sebelum duduk di bangku sekolah (Geske \& Ozola, 2008), belum terlambat untuk diupayakan pada siswa kelas IV. Siswa masih membutuhkan waktu panjang untuk menempuh pendidikan sehingga tidak ada kata terlambat untuk mendidiknya untuk gemar membaca sebagai bagian dari pembentukan karakter mulia. Melalui literasi membaca, anak akan memperoleh banyak manfaat, antara lain menambah kosa kata, memperkaya wawasan dan pengetahuan, meningkatkan imajinasi, membentuk karakter positif, dan menghibur. Di samping itu, membaca juga dapat memperlancar anak membaca untuk kelancaran pendidikan di tingkat selanjutnya. Hal itu ditekankan Pengabdi karena Pengabdi mendapat informasi dari wawancara dengan guru bahwa masih ada siswa kelas IV yang belum lancar membaca. Siswa yang duduk di bangku SD memang diharapkan sudah mampu membaca, tetapi karena kurang adanya stimulus dari lingkungan, anak tidak terbiasa membaca. Ketidakmampuan membaca anak kelas IV, bahkan kelas III, ditemukan pula dalam kegiatan literasi di rusunawa di Jakarta (Wijayanti et al., 2019).

Dari edukasi yang diberikan setidaknya orang tua mulai menyadari bahwa anak perlu diperkenalkan dengan berbagai jenis bacaan. Anak perlu dimotivasi dan didampingi untuk membaca, bila perlu membaca bersama orang tua. Buku yang dinikmati bersama keluarga tidak harus buku pelajaran sekolah. Buku pelajaran sekolah sudah dibuka bersama guru di kelas, tetapi buku nonpelajaran sekolah mungkin tidak pernah dibaca siswa. Dengan membaca buku nonpelajaran sekolah, seperti buku cerita, buku pengetahuan, atau buku petualangan, siswa dapat sejenak refreshing menikmati alur cerita yang menghibur sambil meneladani tokoh yang ada di dalam cerita. 
Peran orang tua sangat besar dalam mendukung minat membaca. Apabila terbiasa dengan membaca buku nonpelajaran sekolah, siswa akan termotivasi untuk membaca buku apa pun, termasuk buku pelajaran, karena pada dasarnya anak sudah suka membaca. Yang ditekankan kepada peserta adalah jangan melarang anak untuk membaca apa pun jenis buku, hadiahi anak dengan buku ketika berprestasi di sekolah atau berulang tahun, dan batasi waktu kebiasaan anak menonton televisi atau menggunakan telepon genggam. Tanpa dukungan dari orang tua mustahil siswa akan terbiasa membaca dan menjadikan membaca sebagai budaya di rumah.

Latar belakang keluarga peserta yang umumnya lulusan SD dengan pendapatan kepala keluarga yang minim merupakan faktor yang menyebabkan perhatian terhadap kebutuhan anak akan bacaan dinomorduakan. Peserta mengakui sudah sibuk dengan pekerjaan di rumah dan antar-jemput anak sekolah sehingga berpikir asalkan keperluan makan sudah tersedia, ia membiarkan anak dengan kesibukannya sendiri. Kondisi seperti ini sejalan dengan kajian sebelumnya yang menemukan bahwa tingkat status sosial dan ekonomi orang tua berpengaruh pada kemampuan literasi anak: anak dengan status sosial ekonomi rendah menunjukkan kemampuan literasi dan sikap membaca rendah dibandingkan mereka yang berstatus tinggi (Hemmerechts et al., 2017; Geske \& Ozola, 2008). Selain sosial ekonomi keluarga, kelemahan literasi membaca dipengaruhi oleh pendidikan orang tua dan kebiasaan orang tua meluangkan waktu untuk membacakan cerita pada anak sebelum anak masuk sekolah (Geske \& Ozola, 2008).

Kondisi ekonomi yang kurang seharusnya bukan hambatan dalam mendorong minat anak membaca. Cara termudah untuk mendorong membaca adalah dengan mengajak anak membaca buku di perpustakaan, baik perpustakaan sekolah maupun perpustakaan di wilayahnya (seperti di TBM atau RPTRA yang berada tidak jauh dari sekolah). Kegiatan bersama anak bukan saja mendekatkan hubungan anak dengan ibunya, melainkan juga memotivasi anak untuk membaca. Aktivitas bersama anak pernah dilaporkan Morrow dan Young (1997, sebagaimana dikutip dalam Sandjaja, 2001) melalui program membaca keluarga. Hasilnya, kegiatan membaca bersama anak dan orang tua berpengaruh pada sikap dan minat membaca anak.

Untuk menerapkan literasi membaca di rumah kepada orang tua, peserta diberikan Proyek Literasi. Orang tua diminta untuk memantau kegiatan membaca anak di rumah saat anak ditugaskan untuk menyelesaikan membaca buku. Kegiatan anak membaca selama seminggu dicatat anak atau orang tua di dalam lembar observasi dan dilaporkan kepada Pengabdi.

\section{Hasil Proyek Literasi}

Dalam kegiatan ini, Pengabdi menghibahkan lima puluh buku cerita fiksi untuk koleksi perpustakaan. Buku-buku tersebut, sebelum disimpan di perpustakaan sekolah, digunakan oleh siswa kelas IV beserta orang tuanya untuk penugasan Proyek Literasi. Masing-masing siswa membaca satu buku hingga selesai dan dapat berganti membaca atau meminjam buku lainnya jika buku yang pertama sudah selesai dibaca. Kegiatan anak ini dipantau orang tua di rumah. Orang tua, khususnya ibu, ditugasi untuk menandatangani kegiatan anak setiap selesai membaca selama seminggu.

Dari $29 \mathrm{ibu}$, yaitu mereka yang hadir dalam kegiatan edukasi dan telah diberikan wawasan mengenai literasi dalam keluarga pada hari pertama, belum seluruhnya menjalankan Proyek Literasi. Hanya lima belas orang tua yang melaporkan hasil observasi literasi. Setelah ditanyakan kepada guru kelas, hal itu disebabkan orang tua tidak mengerti tugas yang 
diberikan. Selain itu, kurang ada koordinasi di dalam keluarga, misalnya yang hadir saat edukasi adalah nenek dari siswa, lalu sang nenek menyerahkan tugas kepada ibu dari siswa, tetapi ibu tersebut tidak sempat menjalakannya.

Dari hasil observasi literasi, diketahui bahwa kegiatan literasi secara umum sudah Wijayanti dilaksanakan dengan baik di rumah. Laporan yang dibuat orang tua siswa menunjukkan bahwa siswa telah membaca buku yang dipinjamkan dari sekolah sampai selesai. Ada siswa yang membaca satu buku dalam seminggu, membaca satu buku dalam empat hari, dan membaca lebih dari satu buku dalam seminggu. Buku yang dibaca meliputi buku cerita dan buku pelajaran. Siswa dan orang tua juga telah mencatat kegiatan literasi dalam lembar observasi. Dalam lembaran tersebut tercatat aktivitas membaca dilakukan siswa secara mandiri atau bersama (orang tua), orang tua mengawasi dan mendampingi anak membaca. Kegiatan mereka selama seminggu terkait literasi adalah membaca, menulis, melihat-lihat gambar buku, dan belajar.

Lembar observasi sebagai bukti dijalankannya Proyek Literasi memuat ringkasan bacaan, tetapi ada pula yang tidak. Ada yang hanya menuliskan informasi tanggal, judul buku yang dibaca, kegiatan yang dilakukan siswa/orang tua, dan tanda tangan orang tua (Gambar 7).
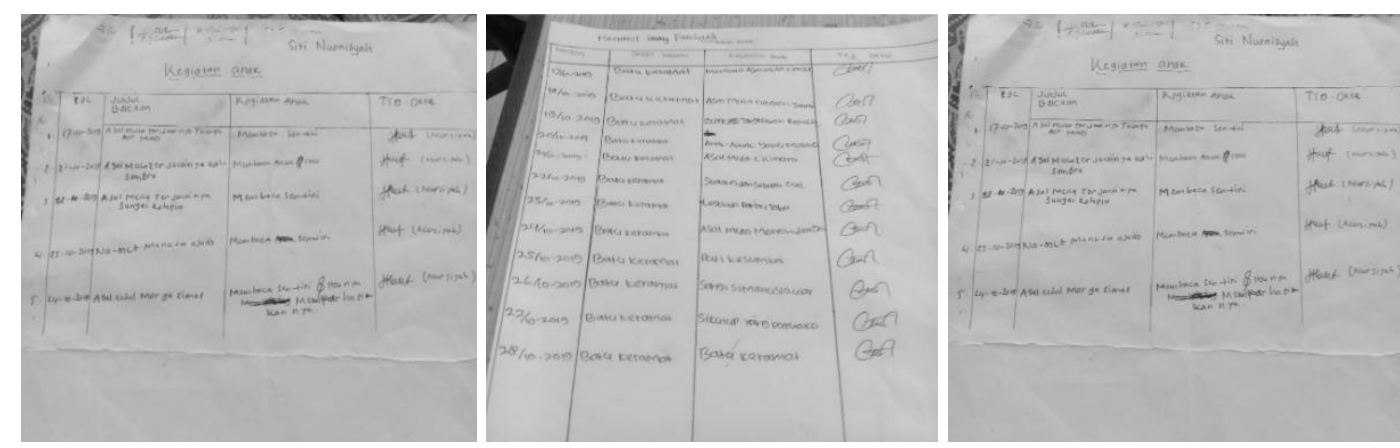

Gambar 7. Laporan literasi siswa

Kegiatan literasi yang melibatkan orang tua siswa baru kali pertama diadakan di SDN Pulau Kelapa 01 Pagi. Upaya membuka wawasan dan memberikan edukasi pentingnya membaca kepada orang tua tentu tidak dapat dalam waktu singkat membuahkan dampak, yaitu orang tua mampu menciptakan suasana literasi di rumah dan mampu membentuk pribadi anak yang gemar membaca. Hal tersebut merupakan kegiatan berjangka panjang yang harus terusmenerus dilakukan. Dengan adanya edukasi yang diikuti dengan Proyek Literasi ini, para ibu diharapkan memiliki pemahaman mendalam bagaimana meliterasi anak karena anak masih memiliki masa depan yang panjang, anak akan banyak belajar baik secara formal maupun informal, serta anak masih perlu dibentuk menjadi siswa yang literat, yaitu siswa yang haus akan ilmu dan informasi sehingga terbiasa memenuhi kebutuhannya itu melalui kegiatan membaca tanpa ada lagi pengawasan dari orang lain. Menurut Wahyuni, hal yang dapat dilakukan untuk mewujudkan siswa yang literat adalah (1) memberikan kebiasaan membaca, (2) menyediakan bacaan, (3) menciptakan suasana kondusif dengan kebiasaan membaca, (4) meningkatkan peran perpustakaan, dan (5) mendesain model pembelajaran yang menyenangkan, bervariasi, dan mendidik (Wahyuni, 2015). 


\section{KESIMPULAN DAN SARAN}

Pihak sekolah telah melakukan pembiasaan pembentukan karakter positif melalui tema-tema yang berbeda setiap harinya meskipun belum sepenuhnya mempraktikkan literasi membaca sesuai dengan pedoman GLS dari pemerintah. Kendati demikian, atmosfer literasi baca-tulis sudah tampak dari adanya mading, pojok baca di beberapa kelas, serta petunjuk-petunjuk tertulis dan simbol-simbol yang dipajang di dalam kelas atau ruang kelas. Namun, sekolah tidak bisa bertindak sendiri. Sekolah perlu bekerja sama dengan orang tua siswa. Edukasi literasi membaca kepada orang tua siswa kelas IV SDN Pulau Kelapa 01 Pagi, Kepulauan Pulau Seribu, telah berhasil dilaksanakan. Para orang tua (ibu) telah memahami bagaimana menciptakan suasana literasi di rumah melalu Proyek Literasi. Namun, dalam praktiknya, Proyek Literasi belum berjalan mulus. Dari 29 peserta edukasi, hanya 15 atau separuh yang menjalankan dan melaporkan hasil Proyek Literasi Membaca.

Pada masa yang akan datang, kegiatan literasi tidak berhenti sampai penugasan literasi saja. Orang tua siswa masih membutuhkan pendampingan agar dapat menerapkan kebiasaan membaca di lingkungan rumah. Dalam hal ini, pihak sekolah perlu bekerja sama dengan orang tua dalam menciptakan suasana literasi yang menyenangkan melalui berbagai kegiatan literasi secara berkesinambungan. Demikian pula, pihak sekolah masih perlu didukung oleh pihak luar, seperti perguruan tingi, untuk mengimplementasi literasi yang telah dicanangkan pemerintah, termasuk pendampingan dalam merealisasikan program-program literasi yang telah dicanangkan dalam rencana kegiatan sekolah.

\section{UCAPAN TERIMA KASIH}

Pengabdi mengucapkan terima kasih kepada semua guru di Sekolah Dasar Negeri Pulau Kelapa 01 Pagi, Kepulauan Seribu, yang telah berpartisipasi dalam keberlangsungan kegiatan ini. Juga kepada Fakultas Ekonomi dan Bisnis, Universitas Katolik Indonesia Atma Jaya, Pengabdi haturkan terima kasih atas dukungan dana yang diberikan pada tahun akademik 2019/2020.

\section{Daftar Pustaka}

Antoro, B. (2018). Gerakan literasi sekolah dari pucuk hingga akar sebuah refleksi. Kementerian Pendidikan dan Kebudayaan Direktorat Jenderal Pendidikan Dasar dan Menengah.

Atmazaki, Ali, M. B. V., Muldian, W., Miftahussuri, Hanifah, N., Nento, M. N., \& Akbari, Q. S. (2017). Panduan Gerakan Literasi Nasional. Kementerian Pendidikan dan Kebudayaan.

Geske, A., \& Ozola, A. (2008). Factors influencing reading literacy at the primary school level. Problems of Education in the 21st Century, 6, 71-77. http://oaji.net/articles/2014/4571392233338.pdf

Hemmerechts, K., Agirdag, O., \& Kavadias, D. (2017). The relationship between parental literacy involvement, socio-economic status and reading literacy. Educational Review, 69(1), 85-101. https://doi.org/10.1080/00131911.2016.1164667

Hidayat, L. (2017). Menumbuhkan ketertarikan membaca anak melalui storytelling. MITRA: Jurnal Pemberdayaan Masyarakat, 1(1), 63-86. https://doi.org/10.25170/mitra.v1i1.7

Kementerian Pendidikan dan Kebudayaan. (2016). Panduan GLS di Sekolah Dasar. Direktorat Pembinaan Sekolah Dasar, Direktorat Jenderal Pendidikan Dasar dan Menengah, Kementerian Pendidikan dan Kebudayaan. 
Palani, K. K. (2012). Promoting reading habits and creating literate society. Journal of Arts, Science \& Commerce, $3,90-94$.

Profil Sekolah SDN Pulau Kelapa 01 Pagi. (2018). SDN Pulau Kelapa 01 Pagi.

Sandjaja, S. (2001). Pengaruh keterlibatan orang tua terhadap minat membaca anak ditinjau dari pendekatan stres lingkungan. Psikodimensia Kajian Ilmiah Psikologi, 1-11.

Susan, S., \& Berthelsen, D. (2014). Shared book reading by parents with young children: Evidencebased practice. Australasian Journal of Early Childhood, 39(1), 49-55.

Wahyuni, S. (2015). Menumbuhkembangkan minat baca menuju masyarakat literat. Diksi, 17(1), 179189. https://doi.org/10.21831/diksi.v17i1.6580

Wardi, T. D. (2020, February 15). Konsep literasi dalam merdeka belajar. Kompas.

Wijayanti, S. H., Efendi, \& Warmiyati, M. M. T. (2012). Peningkatan minat baca melalui peran perpustakaan Sekolah Dasar di Desa Cisauk, Tangerang. Dharmakarya, 1(2), 109-118. http://jurnal.unpad.ac.id/dharmakarya/article/view/8204

Wijayanti, S. H., Utami, N., Pratikto, A., \& Pramono, H. (2019). Menggerakkan literasi Baca-Tulis di Rusunawa Muara Baru, Pluit. Jurnal Bakti Masyarakat Indonesia, 2(2),

https://journal.untar.ac.id/index.php/baktimas/article/view/7234 